differences, institutional responses are generalized and based on gross assumptions of what it means to be "different" and how this difference is constituted as a homogeneity within this identity.

The essentialist construction of identity perpetuates a one-dimensional understanding of diversity. In essentializing difference, the individual is made manageable, knowable, and therefore someone that can be targeted and accommodated within the current mode of decision making. While efforts have been made to institutionally adapt to a diverse penal population, little has been done to disrupt the focus on risk-based decision making. In altering the parole hearing format, selective aspects of identity and diversity are being incorporated without challenging or changing the overall decision-making structure. The way diversity is institutionally defined and identified embodies an approach that is about making exceptions rather than altering the approach to release decision making, "in this context, difference is acknowledged and accommodated in ways that do not challenge dominate institutional practices" (57). The result is modification rather than transformation, with no real questioning of the underlying premise and approach to decision making. In this way adjustments to the process can be implemented without changing the underlying structure, thus maintaining the dominance of risk-based decision-making frameworks. Being seen as doing something, as appearing as though the institution is being responsive to diversity is what matters, rather than the substance of these initiatives.

In questioning the way that diversity is understood and managed, Turnbull asks why modifications that have been made to the release process are not made available for all prisoners. If, for example, the removal of physical barriers and using a more casual, circle format for parole hearings are helpful, should not everyone benefit from these positive changes? Improving the parole hearing process by increasing transparency and accessibility is beneficial for everyone involved. While efforts to change are well-intentioned, Turnbull cautions against trying to make diversity fit within the dominant paradigm.

Nicole Myers

Simon Fraser University

\title{
Jason Garner, Goals and Means: Anarchism, Syndicalism, and Internation- alism in the Origins of the Federación Anarquista Ibérica (Oakland: AK Press, 2016). 384pp. Paperback \$19.00.
}

Jason Garner's Goals and Means: Anarchism, Syndicalism, and Internationalism in the Origins of the Federacion Anarquista Ibérica deals with a familiar topic, the Spanish anarchosyndicalist movement and its flagship organisation, the CNT (Confederación Nacional del Trabajo, National Confederation of Labour); and the run-up to the creation in 1927 of the FAI (Federación Anarquista Ibérica, Iberian Anarchist Federation). Al- 
though its character would evolve in the 1930s, the FAI was envisioned as a partisan group operating within and alongside the unions of the CNT that was used by militant anarchists to coordinate their intervention in the labour movement and to instill anarchist purity in the movement.

Mystery still surrounds the formative period of the FAI, which coincided with the dark years of the Primo de Rivera military dictatorship. Garner's main argument is that the FAI was the anarcho-syndicalists' response to the double challenge posed by the emergence of the communist movement and by the reformist tendencies of the "pure" syndicalists. These conflicts and controversies have to be situated in the difficult years of the 1920s, when the CNT went into decline after a period of intoxicating successes in 1917-20. Its decline mirrored the general crisis of the international anarcho-syndicalist movement, decimated by splits, defections, and by repression. It also followed the brief but intense libertarian infatuation with the Russian Revolution, which led the CNT to fleetingly affiliate with the Third International. The idea of establishing a separate anarchist organisation to bring together like-minded activists and coordinate their intervention in the CNT drew its cues from longstanding traditions of the anarchist movement, going from the First International to the International Anarchist Congress of 1907. Taken as a whole, Garner's argument is compelling; there is little doubt that the FAI was created in response to the challenges of communism and moderate syndicalism, by the need for ideological clarification in the CNT, and by the general difficulties faced by the Spanish labour movement in the 1920s.

The book brings some innovations to the historiography on Spanish anarcho-syndicalism. The national slant of the existing literature on the CNT and the FAI is one of its greatest shortcomings, and the transnational approach of Garner's book opens interesting avenues for research. Despite its notable idiosyncrasies, Spanish anarcho-syndicalism is seen by Garner as part of a global movement with which it was in constant dialogue. His passages on the polemics of the extremist Argentinian anarchists, on the cosmopolitan libertarian milieu of 1920s France, and on the formation and development of the International Workingmen's Association (IWMA) stand out in particular.

Goals and Means takes an explicitly top-down approach, dealing mostly with high-ranking labour activists rather than with the grassroots. A study of the upper echelons of the movement is a legitimate endeavour, although more attention to the relationship between the leading cadre and the rank-and-file would have been welcome, particularly in the last three chapters, when the social backdrop to the political history is almost completely omitted. The overabundance of acronyms and the repeated enumeration of groups, papers, and congresses make some parts of the book hard to follow, and at times one loses sight of the contours of the argument, swamped by a deluge of organisational minutiae.

In terms of sources, Garner has mostly relied on the anarchist press. He has perused it meticulously and has been able to shed light on some historical lacu- 
nae. However, the anarcho-syndicalist press is an obvious and well-utilized source and most of it is well known to the field, and important sources are missing. The absence of memoirs from some of the protagonists is noticeable, such as Gaston Leval, Pere Foix or Jesús Ibáñez. Garner has also concentrated on the best-known newspapers, and has left out many lesser-known publications, especially from the revolutionary years 1917-20. Little work has been done in the Spanish National Historical Archives, which hold much relevant material, and, although Garner has visited the International Institute of Social History in Amsterdam, crucial documents from their collections, such as the minutes from the 1922 Zaragoza conference, have not been used.

The fundamental limitation of the book, nevertheless, is Garner's explicit pro-anarchist ideological agenda. Of course, it need not be a problem that historians feel sympathy for the protagonists of their studies - this can add candour to the account and allows researchers to better understand contemporary views and motivations. But in the case of Garner it has led to an unbalanced engagement with the sources, and to a rather frustrating approach to the topic, where he attempts at all steps to exonerate the anarchists and to censure and dismiss their opponents by repackaging old, highly partisan arguments. The sources and events that do not conform to his narrative are conveniently brushed under the rug. For instance, the anarcho-syndicalists' infatuation with Bolshevism, that lasted from 1917 until at least 1920, and arguably until mid-1921, is presented-like the classic works of anarchist historians such as Buenacasa or Peirats_-as little more than a misunderstanding, produced by the dearth of reliable news from Russia. Considering the importance of the Russian Revolution in the ulterior evolution of the CNT, it is surprising that Garner devotes only eight pages to the matter. To study the rapport between the CNT and the Russian Revolution, he relies on the well-known newspapers Solidaridad Obrera and Tierra y Libertad, which were edited by seasoned cadres and which suspended publication in early 1919 under the blows of repression. This allows Garner to present the anarcho-syndicalists' honeymoon with the Bolsheviks as a passing, emotional phenomenon and to date the divorce to 1919. Had he worked with a wider range of sources he would have realised that the penchant for the Russian Revolution among important sectors of the CNT was more long lasting, deep-rooted, and consequential than he suggests. Garner's superficial engagement with the CNT's support for the Russian Revolution allows him to argue that the pro-Bolshevik "communist-syndicalist" faction that crystallised within the confederation after 1921, and which briefly controlled its national leadership and sanctioned the organisation's affiliation to Moscow's Red International of Labour Unions (RILU), represented a communist ploy to infiltrate the upper echelons of the movement through intrigue. There is little evidence to support this claim, other than biased anarchist accounts from later years, which Garner takes at face value.

Garner's attempt to provide a coherent, cogent image of anarcho-syndicalist ideology, which in these stormy years displayed remarkable mutability and, in- 
deed, inconsistency, leads him to some questionable juggling acts. A clear instance is when he lambasts the communists' "organic link" between the Comintern and the RILU only to go on to defend the trabazón (bond) between the CNT and the FAI. Equally, the syndicalists' apoliticism is initially praised and given as evidence of their primeval libertarian spirit when directed against socialists and communists, but is then attacked when it works against anarchist organisations. These are not the only examples in which important areas are overlooked, downplayed, or exaggerated, to suit Garner's agenda.

Goals and Means contains some persuasive and innovative elements and a broadly cogent argument, but, all in all, the biases of the author make it an unsatisfactory reading and an unwelcome relapse into the traditional anarcho-syndicalist historiography on the CNT.

Arturo Zoffmann Rodriguez

European History Institute

\section{Petrus Liu, Queer Marxism in Two Chinas (Durham, NC: Duke University Press, 2015). 256pp. \$23.95 Paperback.}

In Queer Marxism in Two Chinas Petrus Liu offers a model of queer theory that both challenges homonormative tendencies of mainstream neoliberal gay politics, and pulls on the possibilities of Marxist thought to provide a materialist, structural social analysis. I doubt readers of this journal will need much convincing that assimilationist, inclusion-based political projects are deeply flawed responses to injustice and exclusion, and this premise is of course the bedrock of anything that could rightfully be called "queer theory." At least I have always held to the ideological premise that queer theory and queerness are by definition rooted in analysis and critique of normativity in any area of social/psychic life, including, but not only, sexuality (yet, the sexual is never really absent from the picture it turns out). Challenging neoliberalism - the socio-economic structure that is widely supposed, as Liu points out, to be globally supplanting socialist and traditional liberal social models - is in fact the central agenda of much social theory scholarship; queer theory contributes to these critiques by providing a critical lens on the deeply structured functions of the sexual/gendered within ideologies and practices. However, as Liu presents the state of the field, the radical potential of queer theory is finding itself betrayed by the "homonormative movement" in which "queer" politics become subsumed into the neoliberal order through its assimilationist, normative, and consumerist grounding. "Queer liberalism," a term used to reference homonormative and assimilationist gay politics, is of course a paradox of meaning, but the term identifies the assimilationist bent of neoliberal global gay politics. Liu argues that this global gay politics, rooted in consumeristic, individualistic capitalist society, requires the corrective intervention that Marxist historical materialism can provide. 